\title{
Çocuk Edebiyatındaki Kayıp Mültecilerin İzinde Duyarluluk Eğitimi
}

\section{Sensitivity Training on the Track of Lost Refugees in Child Literature}

\author{
Deniz MELANLIOĞLU ${ }^{1}$
}

${ }^{1}$ Sorumlu yazar/Corresponding author: Deniz Melanlıoğlu (Doç. Dr.), Kırıkkale Üniversitesi Eğitim Fakültesi, Türkçe Eğitimi Anabilim Dalı, Kırıkkale, Türkiye. E-posta: denizmelanlioglu@hotmail.com ORCID: 0000-0002-3663-0894

Bașvuru/Submitted: 25.03 .2020 Revizyon Talebi/Revision Requested: 28.04.2020

Son Revizyon/Last Revision Received:

01.05.2020

Kabul/Accepted: 10.05 .2020

Online Yayın/Published Online: 28.05.2020

Atıf/Citation: Melanlioglu, Deniz. "Cocuk Edebiyatındaki Kayıp Mültecilerin İzinde Duyarlılık Eğitimi." Türkiyat Mecmuası-Journal of Turkology 30, 1 (2020): 161-179.

https://doi.org/10.26650/iuturkiyat.720128

\section{öz}

Suriye Savaşı ile göç ve mültecilik, günlük hayatın bir parçası hâline dönüşmüşken edebiyatın bu konuya kayıtsız kalması mümkün değildir. Ev sahibi toplumun mültecileri nasıl gördüğü ve mültecilerin yeni geldikleri topluma uyum sağlamada ne gibi süreçlerden geçtiği edebiyata zengin bir malzeme sunmaktadır. Ayrıca edebiyat bu anlamda birinin diğerini anlama çabasına, empatik düşünmesine şahitlik etmektedir. Toplumdaki her yaş grubundan bireyin bu anlamda duyarlıı̆̆a sahip olması beklenmektedir. Ön yargıların davranışları gölgelemediği çocukluk döneminde duyarlılığa ilişkin bir eğitim toplumda ileriye dönük huzurun tahsisi için gereklidir, denilebilir. Bu bağlamda çalışmanın amacı, göç ve mültecilik konulu Arkadaşım Korku, Kayıktaki Çocuk, Yolculuk, Tarık ve Beyaz ile Akim Koşuyor adlı çocuk kitaplarını duyarlık eğitimi açısından incelemektir. Bunun için nitel araştırma yöntemlerinden biri olan doküman incelemesi kullanılmış, ulaşılan veriler betimsel analiz ile çözümlenmiştir. Kitaplarda sevgiye duyarlık, kültürel duyarlık, aile bireylerine duyarlık, toplumsal huzura duyarlık, doğaya duyarlık, dilsel duyarlık temel yaşam ihtiyaçlarına duyarlık ve iyilik yapmaya duyarlığın sıklıkla geçtiği tespit edilmiştir. Sonuç olarak içerdiği zengin duyarlık malzemesi ile adı geçen beş kitabın çocukta duyarlığı geliştirebileceği ve duyarlık eğitiminde kullanılabileceği söylenebilir.

Anahtar kelimeler: Çocuk edebiyatı, mülteci, göç, duyarlık eğitimi, Suriye

\section{ABSTRACT}

While the Syrian War, immigration, and refugees have become a part of daily life, it is not possible for literature to remain indifferent to them. In addition to providing rich material to literature through the investigation of how a host society sees refugees and what processes refugees go through to adapt to a new society; the concept of immigration is also important in terms of understanding each other and gaining empathy. Individuals from every age group in society are expected to have sensitivity in this sense. It can be said that training on sensitivity in childhood, when prejudices do not shadow behaviours, is necessary for the establishment of peace among the future generations of society. In this context, the purpose of the study was to examine the children's books named Arkadaşım Korku, Kayıktaki Çocuk, Yolculuk, Tarık ve Beyaz Karga and Akim Koşuyor on the subject of migration and refugee in terms of sensitivity 
training. To this end, a document analysis, one of the qualitative methods, was used and the collected data was analyzed with a descriptive analysis. It was found that the subjects of sensitivity to love, culture, family members, social peace, nature, linguistic sensitivity, basic needs of life, and doing favour are frequently emphasized in the books. In conclusion, the rich content of sensitivity in these five books can develop sensitivity in children and be used in sensitivity training.

Keywords: Children's literature, sensitivity training, refugee, immigration, Syria

\section{EXTENDED ABSTRACT}

In every period of history, humanity has had to deal with various negative situations such as disaster, illness, war, and has often become a witness to these painful experiences. The biggest drama in recent years is the Syrian civil war. While the Syrian War, migration, and refugees have become a part of daily life, it is not possible for literature to remain indifferent to this issue. In addition to providing rich material to literature through the investigation of how a host society sees refugees and what processes refugees go through to adapt to a new society, the concept of immigration is important in terms of understanding each other and gaining empathy. Individuals from every age group in society are expected to have sensitivity in this sense. Sensitivity is defined as "the individual's being interested in what is outside his/her own life, caring about them, not being indifferent to what people live and trying to understand them by empathizing". It can be said that training on sensitivity in childhood, when prejudices do not shadow behaviour, is necessary for the establishment of peace among the future generations of society. In this context, the purpose of the current study was to examine children's books with the subject of immigration and refugee in terms of sensitivity training.

Document analysis, one of the qualitative methods, was used in the current study. Document analysis involves collecting data by analysing existing recordings and documents (Karasar, 2006). In this context, the current study adopted this method to analyze the books making up the study in terms of their contribution to sensitivity training of children and to analyze the collected data in a detailed and holistic manner.

Children's books with the subject of immigration and refugee constituted the data course for the current study. In this connection, the books named Arkadaşım Korku, Kayıktaki Çocuk, Yolculuk, Tarık ve Beyaz Karga and Akim Koşuyor were selected as the data source.

The collected data was analyzed by using the descriptive analysis method. This technique required the summarization and interpretation of collected data according to pre-determined categories. The books with the subject of immigration and refugee included in the study group were analyzed in terms of sensitivity. This analysis was conducted in 16 categories (linguistic sensitivity, sensitivity to love, sensitivity to family members, sensitivity to peace, sensitivity to doing favour, sensitivity to differences, sensitivity to social peace, sensitivity to solidarity, sensitivity to helping each other, sensitivity to diligence, sensitivity to poor people, sensitivity to justice, sensitivity to basic needs of life, sensitivity to science, arts and nature and sensitivity to culture) based and organized on the classification of sensitivity made by Aslan (2013) and Alamdar and Süngü (2017). 
Sensitivity categories determined in the books called Arkadaşım Korku, Kayıktaki Çocuk, Yolculuk, Tarık and Beyaz Karga and Akim Koşuyor with the subject of immigration and refugee are given below.

Six different sensitivities were addressed in Arkadaşım Korku, 11 different sensitivities were addressed in Kayıktaki Çocuk, eight different sensitivities were addressed in Yolculuk, 13 different sensitivities were addressed in Tarı ve Beyaz Karga, and eight different sensitivities were addressed in Akim Koşuyor. These numbers show that the largest number of sensitivities were addressed in Tarık ve Beyaz Karga. Revelation of which categories of sensitivity were more frequently emphasized in the books was important in terms of determining in which categories these books would make children more sensitive. In the analysis conducted in this regard, no statement related to "sensitivity to poor people" was found in the categorization made over 16 categories. The might be associated with the fact that 11 statements were determined for sensitivity to doing favour and 14 statements for sensitivity to helping each other. The categories of sensitivity that came to the fore in the books can be given as follows: sensitivity to love (18), sensitivity to culture (18), sensitivity to family members (17), sensitivity to social peace (15), sensitivity to nature (15), linguistic sensitivity (14), sensitivity to basic needs of life (14) and sensitivity to doing favour (11). This might be because the five books analysed in the current study focused on the subjects of immigration and refugee. The least frequently emphasized categories were found to be sensitivity to science (1) and sensitivity to diligence (1).

The five children's books with the subject of immigration and refugee analysed in the current study were found to present rich materials of sensitivity. In this context, it is thought that the books examined will be useful as a tool in sensitivity training. Through these books, the child gains sensitivity towards respecting people, life, and differences. In addition, these books can be used not only in terms of sensitivity, but also to make children sense the expressive power and creative feature of Turkish. Children who develop linguistic sensitivity feel motivated to read more. Thus, individuals with an effective reader identity can be created, which is one of the most basic functions of children's literature. 


\section{Giriş}

Tarihin her döneminde insanlık; afet, hastalık, savaş gibi çeşitli olumsuz durumlarla mücadele etmek durumunda kalmış, çoğu zaman bu acı tecrübelerin birer tanığı hâline gelmiştir. Özellikle son yılların en büyük dramı Suriye iç savaşıdır. Ülkelerini, evlerini terk etmek zorunda kalan milyonlarca insan, kendilerine güvenli bir yer bulmak için farklı ülkelere yolculuklar gerçekleştirmekte, salgın hastalıklarla, açlıkla mücadele etmektedir. Bu uzun yolculuklar sırasında pek çok kişi hayatını kaybetmekte, geride kalanlar ise sığındıkları ülkelerde birçok problemle karşı karşıya kalmaktadır. Elbette bu sürecin en büyük mağduru yine çocuklar olmaktadır. Sadece bir yıl içerisinde Ege ve Akdeniz'de bin mülteci çocuğun öldüğü ifade edilmektedir ki 2 Eylül 2015’te hayatını yitiren “Aylan bebek" bu vahim tablonun sembolüne dönüşmüştür. Yaşanılan bu drama kayıtsız kalmayan ülkelerin başında gelen Türkiye Cumhuriyeti, bugün Suriyeli mültecilerin $\% 60$ 'ından fazlasına ev sahipliği yapmaktadır. ${ }^{1}$

Ülkelerinden savaş nedeniyle ayrılmak durumunda kalan Suriyeliler; göçmen, mülteci, sığınmacı gibi adlarla anılmaktadırlar. Her ne kadar aynı kavram alanına mensup olsalar da bu sözcükler arasında anlam farklılıkları vardır. Göçmen, "Hür iradesi ile maddi ve sosyal durumunu geliştirebilmek adına bir ülkeye veya bölgeye göç eden kişi."” şeklinde tanımlanırken mülteci, "Irk1, dili, dini, tabiiyeti belirli bir sosyal gruba mensubiyeti ve siyasi görüşleri yüzünden haklı bir zulüm korkusu nedeni ile vatandaşı olduğu ülkenin dışında bulunan ve söz konusu korku yüzünden ilgili ülkenin korumasından yararlanmak isteyen kişi." olarak açıklanmaktadır. ${ }^{3}$ Uluslararası Göç Örgütü tarafından yapılan tanımlar dikkate alındığında Türkiye'de bulunan Suriyelilerin mülteci statüsünde olduğu anlaşılmaktadır. Ancak Suriyelilerin, Türkiye'de yerleşmek maksadında olmadıkları, bir zaruret nedeniyle belirli bir süre misafir edildikleri gerekçesiyle Türkiye Cumhuriyeti, Suriyelileri, mülteci yerine "geçici koruma altında" ifadesi ile nitelemektedir. Bugün gelinen noktada ise Suriyeli misafirlerin, yeni vatanları olarak adlandırdıkları Türkiye'de kalıı ikamet etmek istedikleri bilinmektedir. Bu nedenle çalışmada "geçici koruma altında" ifadesi yerine mülteci kelimesinin kullanımı tercih edilmektedir.

Mültecilerin gelinen topluma uyum süreçlerinde toplumdaki diğer bireylerin desteği önemli bir yere sahiptir. ${ }^{4}$ Zira yaşadıkları ülkeden ayrılmanın, alışkanlıklarından kopmanın yanı sıra mültecilerin yeni toplumun kültürüne uyum sağlama, yeni bir dil öğrenme durumunda kalma, ekonomik baskılanma, aile içi çatışmalar, sosyal statülerini kaybetme, ötekileştirme gibi problemlerle karşı karşıya kaldıkları da bir gerçektir. ${ }^{5}$ Bilindiği gibi yeni topluma uyum

1 Elif Emine Balta, "Çocuk Kitaplarında Mülteciler ve Kültürleşme Stratejileri”, Gaziantep Üniversitesi Sosyal Bilimler Dergisi 17/2 (2018), 487-498.

2 “IOM," Göç Terimleri Sözlüğ̈̈, erişim 23 Şubat 2020, https://publications.iom.int/system/files/pdf/iml31_ turkish_2ndedition.pdf

3 "IOM."

4 Laura Simich, Morton Beiser ve Farah N. Mawani, "Social Support and the Significance of Shared Experience in Refugee Migration and Resettlement", Western Journal of Nursing Research 25/7 (2003), 872-891.

5 Oksana Yakushko, vd., "Immıgration", Ed. R. A. Young, J. F. Domene ve L. Valach, Counselingand Action içinde, (New York: Springer, 2012). 
sağlamanın temel yolu, o toplumun konuştuğu dilin başka bir ifadeyle hedef dilin öğrenimidir. Whitaker da göç eden ailelerin, ev sahibi ülkenin dilini bilme seviyesinin yaşanılan topluma uyumu etkilediğini ifade etmektedir. ${ }^{6}$ Suriyeli mülteciler özelinde Türkçenin öğrenim süreci, sistemli bir eğitim faaliyetini gerekli kılmaktadır. Yetişkinler çeşitli sivil toplum kuruluşları tarafından açılan Türkçe kurslarının yanı sıra halk eğitim merkezlerinde, üniversiteler bünyesindeki dil öğretim merkezlerinde Türkçeyi öğrenirken çocuklar örgün eğitim kurumlarında hedef dili öğrenmektedir. Okul çağındaki Suriyeli çocuk sayısı 1.082.172 iken okula kayıtlı olanların sayısı 684.728 ' dir. ${ }^{7}$ Yaşanılan toplumla uyumun sağlanması, bağların güçlenmesi adına çocuk yaşlarda kurulacak empati, kültürel duyarlılık oldukça önemlidir. Bunun için hem Suriyeli mültecilerin hem de Türk vatandaşlarının karşılıklı anlayışa dayalı bir etkileşim geliştirmeleri gerekmektedir ki bu, çocuklar açısından daha kolay sağlanmaktadır.

Mülteci çocukların içinde bulundukları toplumda yaşadıkları sorunların genelde kötü deneyimler, hayal kırıklığı, duygusal şiddet, sosyal izolasyon, ötekileştirme, yabancı düşmanlığı, reddedilme, kendilerini ifade etme ve kendilerine güvenlerini inşa etme yolu olan oyun ve spor gibi etkinliklerden yoksun kalma, ${ }^{8}$ dil engeli, öğrenme zorluğu, okulda başarısızlık, toplumla uyum sorunu, yoksulluk ve stres olarak yoğunlaştığı görülmektedir. ${ }^{9}$ Siralanan problemler arasında özellikle Türkçe bilmemenin Suriyeli öğrencilerin akran ilişkilerinde başarısız olmalarına neden olduğu ifade edilmektedir. ${ }^{10} \mathrm{Bu}$ durum, akranlarının Suriyeli mültecilere bakış açısını da olumsuz yönde etkilemekte, akranlar arası kültürel duyarlılığın gelişmesini engellemektedir.

Okullarda ortaya çıkan hedef kültür ile kaynak kültür arasındaki farklılıklar, sadece mülteci çocuklar üzerinde değil akranları ve öğretmenleri üzerinde de baskı oluşturmaktadır. Birinin, diğerini anlayabilmesi için karşılıklı empatinin gerçekleşmesi gerekmektedir. Bunun için

6 Elizabeth Whitaker, Language acquisition of thechildren of immigrantsandthe role of nonprofitorganizations (Washington: University of Puget Sound, 2010).

7 PICTES, “Okul Çağındaki Suriyeli Çocuk Sayısı (Broşür)”.

8 “Risk Altındaki Çocuklara İlişkin Psikososyal Destek,” erişim 23 Şubat 2020, https://pictes.meb.gov.tr/izleme/ Content/Dosyalar/02173627_Risk_AltYndaki_Yocuklara_YliYkin_Psikosyal_Destek_Tuncay_Ergene_Antalya_ YalYYtayY.pdf

9 Sema Buz, Türkiye’deki Sı̆̆ınmacıların Üçüncü Bir Ülkeye Gidiş Iç̧in Bekleme Sürecinde Karşılaştıkları Sorunlar (Yüksek Lisans Tezi, Hacettepe Üniversitesi, 2002), Tuğba Yiğit, Uygulamalar ve Sorunlar Bağlamında Türkiye'de Sığınmacı Çocukların Eğitimi (Kırşehir ve Nevşehir Örneği) (Yüksek Lisans Tezi, Ahi Evran Üniversitesi, 2015), Selçuk Akay, Zeynep Hamamcı ve Mahmut Kurt, "Suriyeli Öğrencilerle Çalışan Psikolojik Danışmanların Yaşadıkları Sorunlar ve Bu Sorunlara İlişkin Uyguladıkları Çözüm Yollarının İncelenmesi”, Gaziantep Üniversitesi Ĕgitim Bilimleri Dergisi 1/1 (2017), 23-47., Sema Öngören, vd., "Göçmen Çocukların Yaşadıkları Uyum Problemlerinin Öğretmen Görüşleri Açısından İncelenmesi”, Akademik Sosyal Araştırmalar Dergisi 5/59 (2017), 147-159.

10 Emel Sarıtaş, Ümran Şahin ve Gülsüm Çatalbaş, “İlkokullarda Yabancı Uyruklu Öğrencilerle Karşılaşılan Sorunlar”, Pamukkale Üniversitesi Sosyal Bilimler Enstitüsü Dergisi 25/1 (2016), 208-229., Ceyda Şensin, Sınıf Öğretmenlerinin Suriye'den Göçle Gelen Öğrencilerin Eğitimlerine İlişkin Görüşlerinin Değerlendirilmesi (Yüksek Lisans Tezi, Uludağ Üniversitesi, 2016), Muhammed Şahin ve Yakup Doğan, "Suriyeli öğrencilerin bulunduğu sınıflarda Fen Bilimleri öğretiminde karşılaşılan sorunlar: Nitel bir çalışma", Uluslararası Eğitim Araştırmacıları Dergisi 1/1 (2018), 13-33. 
edebiyatın özellikle, hedef kitlenin özellikleri dikkate alındığında, çocuk edebiyatının etkileşimi sağlama aracı olarak kullanılabileceği düşünülmektedir. Korkmaz, korkunç bir savaşın yıkımına tanıklık etmiş, üstüne mülteciliğin ağır koşullarına mahkûm olmuş milyonların acısını dile getirmenin en etkili yolunun, çocuk edebiyatı olduğunu ifade etmektedir. ${ }^{11}$ Bu sayede çocuğun yaşadıklarını anlamlandırması, bir nebze kolaylaşabilir.

Son yıllarda çocuk edebiyatı alanında verilen eserler incelendiğinde göç, göçmenlik, mültecilik konularına ilişkin çocuk kitaplarının sayısında bir artış olduğu gözlenmektedir. Çocuklara; yaşanan insanlık dramını çocukça anlatabilmek, ön yargıların ortadan kalkmasına vesile olup empati duygusunu geliştirmek, kültürel duyarlılık oluşturmak ve bunu örtük iletilerle çocuğun çıkarım yapmasına izin vererek yapmak ancak çocuk edebiyatının sunduğu imkânlar neticesinde gerçekleşebilir. Mülteci bir çocuk, bu tür kitaplar sayesinde yaşadıklarının sadece kendine özgü olmadığını, hissettiklerinin başka bir çocuk için de geçerli olabileceğini özümserken akranının da ona yönelik empati kurması sağlanarak mülteci arkadaşıyla daha sağlıklı bir iletişim kurması mümkün olabilecektir. Bulut da çocuk kitaplarında bu konuların ele alınmasının sadece mülteci çocuklar için değil ev sahibi toplumun çocuklarının da bu durumu doğru biçimde anlamlandırması için önemli olduğunu ifade etmektedir. ${ }^{12}$ Çünkü göç yalnızca doğdukları topraklardan zorla ayrılmak zorunda kalanları değil, bütün dünyayı ilgilendiren bir olgudur ve buradan çıkarılacak ders; bir anda evsiz, ülkesiz kalmanın aslında herkesin başına gelebilecek ortak bir felaket olduğudur. ${ }^{13} \mathrm{Bu}$ açıdan birinin diğerini anlama çabası, her iki tarafın da "duyarlı olma"sını gerekli kılmaktadır.

\section{Duyarlık ve Duyarlık Eğitimi}

Duyarlık, günümüzde sanal dünyanın getirdiği benmerkezci tutuma karşı bireyde geliştirilmesi gereken önemli bir kavram olarak nitelenmektedir. Duyarlılığın kendiliğinden gelişen bir yapıya sahip olmadığını; öncelikle sevgi, adalet, saygı, dürüstlük, yardımseverlik gibi bazı değerlerin kazanılması gerektiğini ifade eden Aslan duyarlılığı; "bireyin kendi yaşamı dışında olanlara ilgili olması, bunları önemsemesi; insanların yaşadıklarına kayıtsız kalmaması ve onları empati kurarak anlamaya çalışması." şeklinde tanımlamaktadır. ${ }^{14}$ Bireyi duyarlı kılabilmek duyuşsal ve sanatsal bir süreç sonucunda gerçekleştiği için edebiyat, duyarlık geliştirmede etkili bir araç olarak nitelenmektedir. ${ }^{15}$

Sever'e göre çocuk kitaplarının temel amacı; bir şey öğretmek değil, duyarlık kazandırmak olmalıdır. ${ }^{16}$ Bunun için kitaplarda ideal çocuk değil, sorgulayan, bilişsel ve duyuşsal açıdan

11 Safter Korkmaz, "Çocuk Kitaplarında Göç ve Mültecilik”, İyi Kitap Çocuk ve Gençlik Kitapları Dergisi 5 (2017), 1-3.

12 Sevilay Bulut, "Çocuk Edebiyatına Sığınanlar: Zorunlu Göç Öyküleri”, OPUS 8/14 (2018): 384-410.

13 Karin Karakaşl1, "Umut ve Hayal Herkese Lazım”, İyi Kitap Çocuk ve Gençlik Kitapları Dergisi 5 (2017), 8-9.

14 Canan Aslan, "Duyarlık ve Düşünceyi Geliştirmede Çocuk/Gençlik Edebiyatı”, Çoluk Çocuk Dergisi 1/102 (2013), 29-32.

15 Esra Karakuş Tayşi, “Sevim Ak’ın Öykülerinin Duyarlık Eğitimi Açısından İncelenmesi”, Dil ve Edebiyat Araştırmalart 19 (2019), 303-324.

16 Sedat Sever, Çocuk Edebiyatı ve Okuma Kültürü (İzmir:Tudem, 2013). 
dengeli, tartışan, bilime ve sanata saygılı, duyarlı bireylerin yetiştirilmesi hedeflenmelidir. Belirtilen amaca ulaşabilmek için yazar, çocuğun günlük hayatıyla ilişki kurabileceği eserler üretmelidir. Kitaplarda ırkçılık, nefret, düşmanlık, savaş kin, intikam gibi kavramlar "kötü” demek yerine bu kavramların olumsuzluğu çocuğa, karşıt kavramları ile birlikte belirli bir kurgu içinde hissettirilmelidir. ${ }^{17}$

Çocuk edebiyatının öğreticilikten uzak bir üslupla okuru yaşamdaki farklı olay ve olgularla karşılaştırarak duyularını eğitme süreci, duyarlık eğitimi olarak adlandırılmaktadır. Duyarlık eğitiminin amacı; insani değerleri, çocuğun gelişimsel özelliklerini ve yaşını dikkate alarak oluşturulan bir kurguyla çocuğa sezdirmek ve çocukta o konu ile ilgili duyarlık oluşturmaktır. ${ }^{18}$ Binyazar, duyarlık eğitimi almayan bir çocuğun anlayıştan yoksun, empati becerisi gelişmemiş bir kişiliğe sahip olacağını ifade etmektedir. ${ }^{19}$

Kitaplar aracılığıyla verilmek istenen duyarlık eğitiminde neden-sonuç ilişkisi ön planda olduğu için aynı zamanda çocukların eleştirel düşünce becerisi de geliştirilmiş olmaktadır. $\mathrm{Bu}$ nedenle çocuk kitaplarında yaşamın birer gerçeği olan hastalık, ölüm, doğal afetler, boşanma, şiddet, savaş, göç etme, mülteci olma gibi kavramlar bilişsel ve duyuşsal gelişim ile yaş dikkate alınarak belirli sınırlar çerçevesinde çocuğa sunulabilir. ${ }^{20}$ Mültecilik ve kişilerin mülteci olma deneyimlerinin çocuk edebiyatında yer almasının, çocuklarda konuyla ilgili farkındalık oluşturmak için etkili bir yol olduğu düşünülmektedir. ${ }^{21}$ Böylece bu ve benzeri durumlar/olaylar karşısında neler yapılması gerektiğine yönelik bilinç oluşturularak çocukta duyarlık geliştirilebilir. İfade edilenlerden hareketle bu çalışmada çocuk edebiyatında göç ve mültecilik konularını işleyen eserleri, duyarlık eğitimi açısından incelemek amaçlanmaktadır.

\section{Yöntem}

Çalışmada, nitel araştırma yöntemlerinden biri olan doküman incelemesi kullanılmıştır. Doküman incelemesi, doğrudan görüşme ve gözlem yapma imkânının olmadığı durumlarda işe koşulmaktadır. ${ }^{22}$ Doküman incelemesi, var olan kayıt ve belgeleri inceleyerek veri toplamayı içermektedir. ${ }^{23} \mathrm{Bu}$ anlamda çalışma kümesinde yer alan kitapları çocukların duyarlık eğitimine katkısı bağlamında incelemek; verileri ayrıntılı ve bütüncül olarak çözümlemek amacıyla bu yöntem benimsenmiştir.

17 Suphi Güneș Alamdar ve Arzu Süngü, "Nâzım Hikmet'in Sevdalı Bulut Adlı Kitabındaki Masalların Duyarlık Eğitimi Bağlamında İncelenmesi” Ed. Tacettin Şimşek ve Bican Veysel Yıldız, Uluslararası Çocuk ve Gençlik Edebiyatı Sempozyumunda Sunulan Bildiri Kitabl: 1. Cilt içinde, (İstanbul : Step Matbaacılık, 2017), 301-315.

18 Alamdar ve Süngü, "Nâzım Hikmet'in Sevdalı Bulut adlı kitabındaki masalların duyarlık eğitimi bağlamında incelenmesi", 301-305.

19 Adnan Binyazar, "Anadili Kitaplarında Yazınsal Metinlerden Yararlanılarak Duyarlık Eğitimini Gerçekleştirme”, Ed. Hasan Coşkun, İsmail Kaya, J. Kuglin, Türkiye ve Almanya'da İlköğretim Ders Kitapları içinde, (Türk Alman Kültür İşleri Kurulu Yayın Dizisi, No.11, 1996).

20 Alamdar ve Süngü, "Nâzım Hikmet'in Sevdalı Bulut Adlı Kitabındaki Masalların Duyarlık Eğitimi Bağlamında İncelenmesi", 301-305.

21 Bulut, "Çocuk Edebiyatına Sığınanlar: Zorunlu Göç Öyküleri”, 384-410.

22 Ali Yıldırım ve Hasan Şimşek, Sosyal Bilimlerde Nitel Araştırma Yöntemleri (Ankara: Seçkin Yayınc1lık, 2011), 224.

23 Niyazi Karasar, Bilimsel Araştırma Yöntemi (Ankara: Nobel Yayın Dağııım, 2006), 183. 


\section{1. Çalışma Kümesi}

Çalışma kümesinin oluşturulmasında amaçlı örneklemden yararlanılmış bu anlamda göç ve mültecilik konusuna yönelik kaleme alınan çocuk edebiyatı ürünleri, araştırmanın veri kaynağını oluşturmuştur. Buna göre çalışmada kullanılan veri kaynakları şu şekilde gösterilebilir.

Tablo 1. Çalışma Kümesindeki Kitaplara İlişkin Bilgiler

\begin{tabular}{|c|c|c|c|}
\hline Kitabın kodu & Kitabın adı & Kitabın görseli & Kitabın yazarı \\
\hline $\mathbf{K}$ & Arkadaşım Korku & & Francesca Sanna \\
\hline KÇ & Kayıktaki Çocuk & & $\begin{array}{l}\text { Sevde T. Okçu } \\
\text { Maya Mizuno } \\
\text { Vonne Hemels } \\
\text { Golden Sweet }\end{array}$ \\
\hline $\mathbf{Y}$ & Yolculuk & & FrancescaSanna \\
\hline TBK & Tarık ve Beyaz Karga & 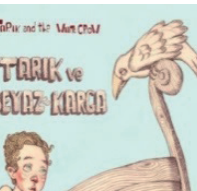 & $\begin{array}{l}\text { Kutup Yıldızı } \\
\text { Kolektifi }\end{array}$ \\
\hline
\end{tabular}

\section{Akim Koşuyor}

AK Akim Koşuyor

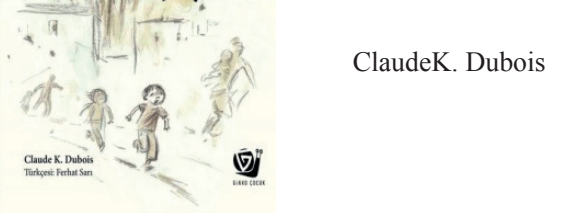


Tablo 1'de çalışma kümesini oluşturan kitaplar, kapak görselleri ve yazarları ile birlikte verilmiştir. Bu kitapların içeriği ise şu şekilde özetlenebilir:

Arkadaşım Korku: Küçük bir kız, ülkesinden uzakta ana dilinin konuşulmadığı bir ülkede yeni bir okula başlar. Okulda küçük kızın yanından hiç ayrılmayan bir arkadaşı vardır, korku. Küçük kız, gittiği ülkedeki konuşulan dili bilmediği için iyice içine kapanır ve korkusuyla arkadaşlık etmeye başlar. Kendi durumunda bir başkasının da olabileceği hiç aklına gelmez. Bu durum, aynı koşullarda bir başka çocukla tanışıncaya kadar devam eder.

Kayıktaki Çocuk: Suriyeli Ahmet'in küçük kayığıyla çıktığı yolculukta Suudi Arabistan, Türkiye, Hollanda, Almanya, Kanada, ABD, Kosta Rika, Japonya gibi ülkelere uğrayarak kendine güvenli bir yuva arayışında başından geçen maceraları konu etmektedir.

Yolculuk: Küçük kız çocuğu ailesiyle birlikte ülkesini terk etmek zorunda kalır. Kendini göç ettiği için kuşlarla özdeşleştiren küçük kız, onların sınır geçmek zorunda kalmadığını fark eder. Hayatları değişen küçük kız ve ailesi, ülkelerinden çok uzakta, sınırlar arasında geçen mücadeleleri sırasında umutlarını hiç kaybetmezler.

Tarık ve Beyaz Karga: Tarık ve ailesi, küçük, güzel bir adada dostlarıyla birlikte mutlu bir şekilde yaşar. Ancak bir sabah adalarının üzerine kara bir bulut yerleşir ve sonu gelmez yağmurlara neden olur. Artık yağmurlara dayanamayan Tarık ve babası yeni bir ada bulmak üzere denize açılır, bu yolculukta yalnız değillerdir, onlara beyaz bir karga rehberlik eder. Böylece kendilerine yeni bir ada bulurlar ancak ada halkı, Tarık ve babasını hemen kabullenemez ve beklenmedik olaylar gelişir.

Akim Koşuyor: Bir nehir kenarında arkadaşlarıyla birlikte oyun oynayan Akim, gelen silah sesleri ile irkilir ve köydeki herkesle beraber koşmaya başlar. Eve gidip ailesini bulmaya çalışır ama eve gittiğinde evinin yerle bir olmuş hâlini görür, ailesine ulaşamaz. Ona yardım etmek isteyenlerle birlikte koşmaya başlayan Akim'in ailesini arama mücadelesi, beklenmedik bir şekilde son bulur.

İncelenen kitaplar her ne kadar çocuk kitapları olarak nitelense ve bu çalışmada çocuk duyarlığı açısından değerlendirilse de bu kitaplar, hem çocuk hem de yetişkin okurlar için zengin bir mültecilik deneyimi sunmakta ve mültecilik olgusunun ne olduğuna dair bir fankındalık oluşturmaktadır. Bu nedenle çalışma kümesinde yer alan kitaplar için bir yaş düzeyi belirtilmemiştir.

\subsection{Verilerin Analizi}

Veriler, betimsel çözümleme tekniği kullanılarak analiz edilmiştir. Bu tekniğe göre elde edilen veriler daha önceden belirlenen kategorilere göre özetlenmekte ve yorumlanmaktadır. Bunun için elde edilen bulgular, önce dizgesel ve açık bir biçimde betimlenmekte daha sonra bu betimlemeler açıklanıp yorumlanarak birtakım bulgu ve sonuçlara ulaşılmaktadır. ${ }^{24}$ Ulaşılan bulgu ve sonuçları yansıtmak amacıyla çalışmada doğrudan alıntılara sık sık yer verilmektedir.

24 Yıldırım ve Şimşek, Sosyal Bilimlerde Nitel Araştırma Yöntemleri 
Çalışma kümesinde belirtilen göç ve mültecilik konulu çocuk kitapları, duyarlık bağlamında çözümlenmiştir. Bu çözümlemede Aslan ile Alamdar ve Süngü’nün yaptığı duyarlık kategorileri esas alınarak bir düzenleme yapılmıştır. ${ }^{25}$ Araştırma kapsamında dikkate alınan kategoriler şunlardir:

Tablo 2. Araştırma Kapsamında İncelenen Duyarlık Kategorileri

\begin{tabular}{ll}
\hline 1.Dilsel duyarlık & 9. Çalışkanlığa duyarlık \\
2. Sevgiye duyarlık & 10. Yoksul insanlara duyarlık \\
3. Aile bireylerine duyarlık & 11. Adalete duyarlık \\
4. Barışa duyarlık & 12. Temel yaşam ihtiyaçlarına duyarlık \\
5. İyilik yapmaya duyarlık & 13. Bilime duyarlık \\
6. Farklılıklara duyarlık & 14. Sanata duyarlık \\
7. Toplumsal huzura duyarlık & 15. Doğaya duyarlık \\
8. Yardımlaşmaya duyarlık & 16. Kültürel duyarlık
\end{tabular}

Tablo 2'de belirtilen kategorilere göre incelenen kitaplardaki ifadeler belirlenmiş ve fişlenmiştir. Kitaplarda saptanan duyarlık sayıları çıkartılmış ve saptanan duyarlıklara ilişkin eserlerden alıntı yapılarak örnekler sunulmuştur. Duyarlık kodları için Tablo 2'de verilen sayılardan yararlanılmıştır. Araştırma kapsamındaki kitaplara yönelik bilgi ise Tablo 1'de her bir kitap için oluşturulan kodlarla gösterilmiştir. Çalışma kümesinde yer alan eserler, araştırmacı dışında iki alan uzmanı tarafından okunmuş ve kitaplarda geçen duyarlığa yönelik ifadeler alan uzmanlarınca da fişslenmiştir. Daha sonra araştırmacı ve alan uzmanları bir araya gelerek belirledikleri ifadeler karşılaştırılmış, farklı tespitlere yönelik ilgili bölümler yeniden gözden geçirilmiştir. Görüş birliği sağlanan ifadeler, bulgular bölümüne aynen taşınırken görüş birliği sağlanamayan ifadeler çalışma kapsamından çıkarılmıştır. Böylece nitel araştırmanın doğasına özgü geçerlik ve güvenirlik sağlanmaya çalışılmıştır. ${ }^{26}$

\section{Bulgular}

Göç ve mültecilik konulu Arkadaşım Korku, Kayıktaki Çocuk, Yolculuk, Tarık ve Beyaz Karga ile Akim Koşuyor adlı çocuk kitapları, duyarlık eğitimi açısından incelenmiş, eserlerde geçen duyarlık kategorileri, alıntı cümlelerle örneklenmiş, hangi kitapta hangi duyarlık kategorilerinin yer aldığı, hangisinin/hangilerinin öncelendiği tespit edilmiştir. Buna göre Tablo 3 'te eserler ve bu eserlerde yer alan duyarlık kategorileri ifade edilmiştir.

25 Aslan, "Duyarlık ve Düşünceyi Geliştirmede Çocuk/Gençlik Edebiyatı", 29-32., Alamdar ve Süngü, "Nâzım Hikmet'in Sevdalı Bulut adlı kitabındaki masalların duyarlık eğitimi bağlamında incelenmesi”, 301-305.

26 Gökhan Arastaman, İnci Öztürk Fidan ve Tuncer Fidan, "Nitel Araştırmada Geçerlik ve Güvenirlik: Kuramsal Bir İnceleme”, YYÜ Ĕgitim Fakültesi Dergisi 15/1 (2018), 37-75. 
Tablo 3. Çocuk Kitapları ve Duyarlık Kodları

\begin{tabular}{|c|c|c|c|}
\hline Kitabın kodu & $\begin{array}{l}\text { Kitabın } \\
\text { adı }\end{array}$ & $\begin{array}{l}\text { Duyarlık } \\
\text { kodu }\end{array}$ & $\begin{array}{l}\text { Kazandıracağı } \\
\text { duyarlık }\end{array}$ \\
\hline \multirow{6}{*}{$\mathbf{K}$} & \multirow{6}{*}{ Arkadaşım Korku } & 1 & Dilsel duyarlık \\
\hline & & 2 & Sevgiye duyarlık \\
\hline & & 5 & İyilik yapmaya duyarlık \\
\hline & & 6 & Farklılıklara duyarlık \\
\hline & & 8 & Yardımlaşmaya duyarlık \\
\hline & & 16 & Kültürel duyarlık \\
\hline \multirow{11}{*}{ KÇ } & \multirow{11}{*}{ Kayıktaki Çocuk } & 1 & Dilsel duyarlık \\
\hline & & 2 & Sevgiye duyarlık \\
\hline & & 4 & Barışa duyarlık \\
\hline & & 5 & İyilik yapmaya duyarlık \\
\hline & & 7 & Toplumsal huzura duyarlık \\
\hline & & 8 & Yardımlaşmaya duyarlık \\
\hline & & 11 & Adalete duyarlık \\
\hline & & 12 & Temel yaşam ihtiyaçlarına duyarlık \\
\hline & & 14 & Sanata duyarlık \\
\hline & & 15 & Doğaya duyarlık \\
\hline & & 16 & Kültürel duyarlık \\
\hline \multirow{8}{*}{$\mathbf{Y}$} & \multirow{8}{*}{ Yolculuk } & 3 & Aile bireylerine duyarlık \\
\hline & & 4 & Barışa duyarlık \\
\hline & & 7 & Toplumsal huzura duyarlık \\
\hline & & 11 & Adalete duyarlık \\
\hline & & 12 & Temel yaşam ihtiyaçlarına duyarlık \\
\hline & & 14 & Sanata duyarlık \\
\hline & & 15 & Doğaya duyarlık \\
\hline & & 16 & Kültürel duyarlık \\
\hline \multirow{13}{*}{ TBK } & \multirow{13}{*}{ Tarık ve Beyaz Karga } & 1 & Dilsel duyarlık \\
\hline & & 2 & Sevgiye duyarlık \\
\hline & & 3 & Aile bireylerine duyarlık \\
\hline & & 5 & İyilik yapmaya duyarlık \\
\hline & & 6 & Farklılıklara duyarlık \\
\hline & & 7 & Toplumsal huzura duyarlık \\
\hline & & 8 & Yardımlaşmaya duyarlık \\
\hline & & 9 & Çalışkanlığa duyarlık \\
\hline & & 12 & Temel yaşam ihtiyaçlarına duyarlık \\
\hline & & 13 & Bilime duyarlık \\
\hline & & 14 & Sanata duyarlık \\
\hline & & 15 & Doğaya duyarlık \\
\hline & & 16 & Kültürel duyarlık \\
\hline \multirow{8}{*}{ AK } & \multirow{8}{*}{ Akim Koşuyor } & 2 & Sevgiye duyarlık \\
\hline & & 3 & Aile bireylerine duyarlık \\
\hline & & 4 & Barıșa duyarlık \\
\hline & & 5 & İyilik yapmaya duyarlık \\
\hline & & 7 & Toplumsal huzura duyarlık \\
\hline & & 8 & Yardımlaşmaya duyarlık \\
\hline & & 12 & Temel yaşam ihtiyaçlarına duyarlık \\
\hline & & 14 & Sanata duyarlık \\
\hline
\end{tabular}


Tablo 3 incelendiğinde Arkadaşım Korku'da 6, Kayıktaki Çocuk adlı kitapta 11, Yolculuk kitabında 8, Tarık ve Beyaz Karga'da 13, Akim Koşuyor'da ise 8 farklı duyarlılığa yer verildiği görülmektedir. Bu da göstermektedir ki duyarlılık içeren ifadeler en fazla Tarık ve Beyaz Karga' da bulunmaktadır. Kitapların hiçbirinde "yoksul insanlara duyarlık" kategorisinde değerlendirilebilecek bir ifadeye rastlanmamıştır.

Arkadaşım Korku, Kayıktaki Çocuk ile Tarık ve Beyaz Karga'da dilsel duyarlığa yönelik ifadelerin varlığı dikkat çekmektedir. Arkadaşım Korku'da bir dili bilmenin etkileşim açısından önemi vurgulanırken Kayıktaki Çocuk ile Tarık ve Beyaz Karga'da Türkçenin zengin söz varlığının bir yansıması olan atasözü, deyim gibi kalıp ifadelerin yanı sıra Türkçenin betimlemelerde nasıl bir zenginlik sunduğu da gözler önüne serilmektedir.

Sevgi, her insan için bir gereksinimdir. İncelenen kitaplar özelinde arkadaş sevgisinin işlendiği anlaşılmaktadır. Arkadaşım Korku, Kayıktaki Çocuk ile Tarık ve Beyaz Karga'da sevgiye duyarlık kurulan arkadaş ilişkileri bağlamında çocuk okura sunulurken Akim Koşuyor' da bu ilişkinin arkadaştan yoksunluk üzerinden kurulduğu görülmektedir.

Aile, toplumdaki her birey için özel bir kavramdır. Göç ve mülteciliğin getirdiği olumsuz sonuçlardan biri de parçalanmış ailelerdir. Yolculuk ve Akim Koşuyor'da okur, parçalanmış ailelerin dramına şahitlik etmektedir. Her iki kitapta da "anne" vurgusu oldukça dramatik ögeler barındırmaktadır. Tarık ve Beyaz Karga kitabında ise anne, baba, kardeş, büyükanne, büyükbaba gibi geniş ailenin bir araya geldiği mutlu bir son bulunmaktadır.

Savaşın olmadığı barış ortamında bir yaşam her insan için temel bir haktır. Barışın olduğu bir toplum; hak ve hukukun gözetildiği huzurlu bir görünüm sergilemektedir. Bu anlamda toplumsal huzura duyarlığa yönelik ifadeler; Kayıktaki Çocuk, Yolculuk, Tarık ve Beyaz Karga ile Akim Koşuyor'da bulunurken adalete duyarlık, Kayıktaki Çocuk ve Yolculuk kitaplarında ele alınmaktadır. Bütün bunların bir yansıması olan barışa duyarlık ise Kayıktaki Çocuk, Yolculuk ve Akim Koşuyor'da vurgulanmaktadır.

İyilik yapma ve yardımlaşma, toplumsal dayanışmayı artıran, insanlar arası etkileşimi geliştiren bir niteliğe sahiptir. Göç ve mültecilik özelinde bakıldığında bu kavramların önemi, farklı bir değer kazanmaktadır. Arkadaşım Korku, Kayıktaki Çocuk, Tarık ve Beyaz Karga ile Akim Koşuyor'da hem iyilik yapmaya hem de yardımlaşmaya duyarlığın okura etkileyici bir biçimde sunulduğunu söylemek mümkündür.

İnsanın fizyolojik, güvende olma, ait olma, değer görme gibi birtakım temel gereksinimleri vardır. Bu gereksinimler içerisinde fizyolojik ihtiyaçların giderilememesi diğerlerini de olumsuz yönde etkilemektedir. Kayıktaki Çocuk, Yolculuk ile Tarık ve Beyaz Karga'da temel yaşam ihtiyaçlarına duyarlığa ilişkin ifadelerin genellikle fizyolojik ihtiyaçlarla, Akim Koşuyor kitabında ise güvende olmayla ilişkili olduğu anlaşılmaktadır.

Tarık ve Beyaz Karga adlı eserde ada sakinlerinin karşılaştıkları soruna çözüm olarak rüzgâr makinesi geliştirmeleri bilime duyarlılığı örneklemektedir. Ayrıca Tarık ve Beyaz Karga, incelenen kitaplar arasında çalışkanlığa duyarlığı örnekleyen tek kitap olma özelliğine sahiptir. 
Bir sanat dalı olarak edebiyatın, okurda bir estetik zevk inşa etmesinin yanı sıra diğer sanat dallarına yönelik farkındalık oluşturması da önemlidir. Kayıktaki Çocuk, Yolculuk, Tarık ve Beyaz Karga ile Akim Koşuyor'da sanata duyarlık ifadelerine yer verilmektedir. Akim Koşuyor, kahramanına Binbir Gece Masalları’nı dinleterek aynı zamanda bir metinler arası gönderimde de bulunmaktadır. Tarık ve Beyaz Karga'da müzik sanatı, kahramanın çaldığı flüt üzerinden işlenmektedir.

İncelenen kitaplarda doğanın kimi zaman insan hayatını güzelleştiren kimi zaman da zorlaştıran yönlerinin ön plana çıkarıldığı görülmektedir. Kayıktaki Çocuk, Yolculuk ile Tarık ve Beyaz Karga eserlerinde orman, deniz, hayvanlar vb. vurgular yapılarak çocuk okurda doğaya duyarlık oluşturmak amaçlanmıştır, denilebilir.

Göçün ve mülteciliğin getirdiği yeni bir yer hayali; gidilen yerdeki farklılıkları kendince değerlendirme ve yeni yere uyum sağlama, beraberinde farklılıklara saygı duymayı gerektirmektedir. Arkadaşım Korku ile Tarık ve Beyaz Karga' da bu vurgunun yapıldığı görülmektedir. Yeni bir ülke aynı zamanda yeni bir dil ve yeni bir kültür demektir. Bu bağlamda kültürel duyarlık geliştirmek, çocuk okurun bu kavramları anlaması ve içselleştirmesi açısından önemlidir. Arkadaşım Korku, Kayıktaki Çocuk, Yolculuk, Tarık ve Beyaz Karga kültürel duyarlık ifadeleri açısından zengin bir malzeme sunmaktadır. Özellikle Kayıktaki Çocuk adlı kitap kültürel duyarlık bakımından üzerinde ayrıca çalışma yapılması gereken bir malzeme barındırmaktadır.

İncelenen çocuk kitaplarında hangi kategoriye yönelik duyarlılığın daha çok görüldüğünün ortaya konması, beş kitabın çocuğu hangi kategoride daha çok duyarlı kılabileceğinin tespiti noktasında önemlidir. Tablo 4'te hangi duyarlık türünün hangi kitapta ne sıklıkla geçtiğine dair sayısal veriler paylaşılmaktadır.

Tablo 4. Duyarlık Kategorilerinin Kitaplarda Geçme Sıklığı

\begin{tabular}{|c|c|c|c|c|c|c|}
\hline \multirow[b]{2}{*}{ Duyarlıklar } & \multicolumn{5}{|c|}{ Kitaplar } & \multirow[b]{2}{*}{ Toplam } \\
\hline & $\mathbf{K}$ & KÇ & $\mathbf{Y}$ & TBK & AK & \\
\hline 1. Dilsel duyarlık & 4 & 5 & - & 5 & - & 14 \\
\hline 2. Sevgiye duyarlık & 4 & 7 & - & 4 & 3 & 18 \\
\hline 3. Aile bireylerine duyarlık & - & - & 5 & 8 & 4 & 17 \\
\hline 4. Barışa duyarlık & - & 1 & 1 & - & 1 & 3 \\
\hline 5. İyilik yapmaya duyarlık & 2 & 2 & - & 3 & 4 & 11 \\
\hline 6. Farklılıklara duyarlık & 2 & - & - & 2 & - & 4 \\
\hline 7. Toplumsal huzura duyarlık & & 5 & 3 & 4 & 3 & 15 \\
\hline 8. Yardımlaşmaya duyarlık & 3 & 3 & - & 3 & 5 & 14 \\
\hline 9. Çalışkanlığa duyarlık & - & - & - & 1 & - & 1 \\
\hline 10. Yoksul insanlara duyarlık & - & - & - & - & - & - \\
\hline 11. Adalete duyarlık & - & 4 & 3 & - & - & 7 \\
\hline 12. Temel yaşam ihtiyaçlarına duyarlık & - & 2 & 3 & 4 & 5 & 14 \\
\hline 13. Bilime duyarlık & - & - & - & 1 & - & 1 \\
\hline 14. Sanata duyarlık & - & 1 & 2 & 3 & 1 & 7 \\
\hline 15. Doğaya duyarlık & - & 8 & 2 & 5 & - & 15 \\
\hline 16. Kültürel duyarlık & 4 & 10 & 1 & 3 & - & 18 \\
\hline
\end{tabular}


Tablo 4'e bakıldığında kitaplarda ön plana çıkan duyarlık kategorilerinin sırayla sevgiye duyarlık (18), kültürel duyarlık (18), aile bireylerine duyarlık (17), toplumsal huzura duyarlık (15), doğaya duyarlık (15), dilsel duyarlık (14), temel yaşam ihtiyaçlarına duyarlık (14) ve iyilik yapmaya duyarlık (11) olduğu anlaşılmaktadır. Bu durum, incelenen beş kitabın konu bakımından göç ve mültecilik kavramlarına odaklanmasının bir sonucu olarak değerlendirilebilir. Bilime duyarlık (1) ve çalışkanlığa duyarlık (1) ise kitaplarda en az yer verilen kategorilerdir. Çalışma kümesindeki kitaplarda “yoksul insanlara duyarlık”a yönelik bir ifadeye rastlanmamıştır. Bunun nedeni, iyilik yapmaya duyarlık için 11, yardımlaşmaya duyarlık için 14 ifadenin bulunması ile ilişkilendirilebilir. Kitapların analizi neticesinde tespit edilen duyarlıklar ve bu duyarlıları örnekleyen ifadeler Tablo 5'te belirtilmektedir.

Tablo 5. Tespit Edilen Duyarlıklara İlişkin Kitaplardan Alıntı Yapılan İfadeler

\begin{tabular}{|c|c|}
\hline $\begin{array}{c}\text { Kitap ve } \\
\text { duyarlık kodu }\end{array}$ & Örnek ifadeler \\
\hline $\mathrm{K}-1$ & $\begin{array}{l}\text { Korku okulu pek sevmiyor. Öğretmen adımı yanlış söylediğinde sinirleniyor ve daha da büyüyor. } \\
\text { Ben öğretmenimin istemeden yanlış söylediğini biliyorum ama gel de Korku'ya bunu anlat. (s. 11) } \\
\text { Kimse beni anlamıyor. Ben de kimseyi anlamıyorum. (s. 14) }\end{array}$ \\
\hline $\mathrm{K}-2$ & Tanıştırayım, arkadaşım Korku. O benim herkesten gizlediğim sırrım. (s. 3) \\
\hline K-5 & Korku her zaman beni koruyup kolladı. Tehlikelerden uzak tuttu. (s. 4) \\
\hline K-6 & $\begin{array}{l}\text { Bahçede koşmaya başladık. Birden parmaklıkların arkasından bir köpek havlamaya başladı. } \\
\text { "Aaaaaaaayyyh” diye çığlık attı çocuk ve küçük tuhaf bir şeyin arkasına saklandı. Onun da } \\
\text { benimkisi gibi gizli bir korkusu varmıs. Oysa sadece benim var sanıyordum. (s. 26-29) } \\
\text { Ama sınıftaki diğer çocukların da kendi korkuları olduğunu görmeye başladım. (s. 31) }\end{array}$ \\
\hline $\mathrm{K}-8$ & $\begin{array}{l}\text { Ama bir gün çok ilginç bir şey oldu. Sinıftan bir çocuk bana bir şey göstermek istedi. Sonra } \\
\text { birlikte resimler yapmaya, boyamaya başladık. (s. 22-23) }\end{array}$ \\
\hline $\mathrm{K}-16$ & $\begin{array}{l}\text { Ama bu yeni ülkeye geldiğimizden beri, küçük dostum Korku artık pek küçük değil. Büyüdükçe } \\
\text { büyüyor. Boyu beni çoktan geçti. (s. 6-7) }\end{array}$ \\
\hline KÇ-1 & $\begin{array}{l}\text { Ahmet denize açıldı, sanki gökyüzü de Ahmet için açıldı. Kayığıyla bir balık gibi süzüldü... } \\
\text { Düşleri aydınlık, gözleri kara kömür. Düşündü merakla, yeni evim nerede acaba? (s.6). } \\
\text { Ahmet bu sefer küçük kayığıyla okyanusları aştı. Her yerin bembeyaz karlarla kaplı bir ülkeye geldi. } \\
\text { Pamuk tepelerde bata çıka yürürken kardan adam yapan ponpon şapkalı bir kızla karşılaştı. (s.33) }\end{array}$ \\
\hline KÇ-2 & $\begin{array}{l}\text { Gece saçlı bir kız ona selam verdi. Hemen arkadaş oldular. Birlikte oyun oynadılar, güzel } \\
\text { yemişler yediler ve aynı dilde şarkılar söylediler. (s.9). } \\
\text { Balina şeklinde uçurtması olan bir çocukla karşılaştı. Ahmet çocukla hemen kaynaştı. Yemyeşil } \\
\text { tepelerde koştular, âdeta uçurtmaya yarıştılar. (s.17) } \\
\text { Yeni bir yuvanın hasretiyle küçük kayığında yalnız uyudu. (s. 38) }\end{array}$ \\
\hline KÇ-4 & $\begin{array}{l}\text { Haydi, bakalım çocuklar hepiniz yanıma gelin. Buradan dünya nasıl gözüküyor, sizlere } \\
\text { göstereyim. Çocuklar Dolunay anneye ulaştıklarında dünyaya hayretle baktılar. "Sınırlar yok, tüm } \\
\text { dünya hepimizin!" diye haykırdılar. "Şimdi büyükleri uyandırma zamanı! Haydi, dünyaya geri } \\
\text { dönelim! Doğan her çocuğun eşit ve özgür olduğunu onlara söyleyelim." (s. 41-43) }\end{array}$ \\
\hline KÇ-5 & $\begin{array}{l}\text { Hayran hayran etrafina bakarken balık tutan mavi gözlü bir çocukla tanıştı. Kol kola girip deniz } \\
\text { kenarında yürümeye başladılar. Vapurlara el sallayıp martılara ekmek attılar. ( s.13). }\end{array}$ \\
\hline KÇ-7 & Fakat dünya çocuklarının desteğiyle artık Ahmet mutlu ve güvende.(s.44) \\
\hline KÇ-8 & $\begin{array}{l}\text { "Yağmur yağıyor, gel şemsiyemin altına gir.” Dedi altın saçlı kız. Birlikte yürümeye başladılar. } \\
\text { Yağmurda birikmiş suların üzerinde hoplaya hoplaya gezdiler. ( s.21) } \\
\text { "Burası çok güzel, sence bir süre kalabilir miyim?” Elbette canım, tabii ki kal, zaten milyonlarca } \\
\text { misafirimiz var. (s. 13) }\end{array}$ \\
\hline
\end{tabular}




\begin{tabular}{|c|c|}
\hline KÇ-11 & $\begin{array}{l}\text { Üzülme, eminim bir yer bulacaksın kalacak, bizim devletimiz size çok yardım etmiş, gözüm } \\
\text { arkada kalmayacak. (s. 9) } \\
\text { Ah! Keşke... Fakat duyduğuma göre başka ülkelerin yardımı olmadan çok zormuş burada } \\
\text { kalman... (s. 21) }\end{array}$ \\
\hline KÇ-12 & Köşedeki büfeden simide benzeyen çok lezzetli bir yiyecek aldılar. (s. 21) \\
\hline KÇ-14 & $\begin{array}{l}\text { Küçük kız Ahmet'e gülümsedi, kâğıtlardan yaptığı origamileri gösterdi. Birlikte turna, kuğu, } \\
\text { ejderha origamileri yaptılar. Ahmet çok eğlendi! (s.37) }\end{array}$ \\
\hline KÇ-15 & $\begin{array}{l}\text { Uzaktan geçen kocaman boynuzlu geyikleri mutlulukla izlediler. (s.25) } \\
\text { Birlikte parkı gezdiler hatta sonra ağaçlardaki sincapları seyrettiler. (s. 29) } \\
\text { Palmiyelerin, hindistancevizi ağaçlarının ve şipşirin maymunların olduğu kumsalı görünce } \\
\text { gözleri kamaştı. (s. } 33 \text { ) } \\
\text { Ahmetcik tek başına ne yapar o minicik kayıkta? Tam o esnada gökyüzünden gelen bir ses } \\
\text { konuşmaları böldü. Dolunay anne hepsini sevgiyle süzdü.(s. 41) }\end{array}$ \\
\hline KÇ-16 & $\begin{array}{l}\text { Keşke kalabilsen... Çok güzel bir kalbin var. Fakat büyünce burada sorun çıkarırsın sanıyor } \\
\text { ülkemizdeki insanlar. (s.29) } \\
\text { Kıvırcık saçlı çocuk elindeki son dilim mangoyu Ahmet'e uzatırken cevapladı: İstediğin şey } \\
\text { mümkün değil maalesef buraya uyum sağlayamazsın diye düşünüyor herkes. (s.33) } \\
\text { Harika olurdu ama buradakiler seni çok yargılar onlara benzemiyorsun diye seninle konuşmazlar. } \\
\text { (s.37) }\end{array}$ \\
\hline Y-3 & $\begin{array}{l}\text { Annem, babam, ben ve kardeşim denize çok yakın bir şehirde yaşıyoruz. Yaz aylarında hafta sonu } \\
\text { tatillerimizi hep kumsalda geçiririz. (s. 1) } \\
\text { Annem hâlâ birlikte olduğumuz için çok şanslı olduğumuzu söyledi. (s. 36) }\end{array}$ \\
\hline Y-4 & $\begin{array}{l}\text { Ne mi oldu? Savaş başladı. Her gün etrafımızda korkunç şeyler olmaya başladı. Çok geçmeden } \\
\text { çevremizde kargaşadan başka bir şey göremez olduk. Sanki dünyanın bütün 1şıklarını } \\
\text { söndürüyorlardı. (s. 4) }\end{array}$ \\
\hline Y-7 & O günden sonra etrafımızdaki karanlık daha da büyüdü ve annemin endişeleri daha da arttı. (s. 7) \\
\hline Y-11 & $\begin{array}{l}\text { İyice uzaklaşana kadar durmadan koştuk. Sonra birden daha önce hiç görmediğimiz bir adamla } \\
\text { karşılaştık. Annem adama biraz para verdi. Adam bizi sınırın diğer tarafına geçirdi. Çok } \\
\text { karanlıktı. Kimse bizi görmemişti. (s. 27) }\end{array}$ \\
\hline $\mathrm{Y}-12$ & $\begin{array}{l}\text { Kuşlar da aynı bizim gibi göç ediyorlardı. Onların yolculuğu da çok uzundu ama hiç sınır geçmek } \\
\text { zorunda değillerdi. Belki bir gün aynı bu kuşlar gibi biz de yeni bir yuva buluruz. Hikâyemize } \\
\text { yeniden başlayabileceğimiz güvenli bir yuva... (s. 39) }\end{array}$ \\
\hline Y-14 & $\begin{array}{l}\text { Yol boyunca teknedekilerle birbirimize masallar anlattık. Öyle perili, prensesli masallar değildi } \\
\text { ama... Denizin altında saklanan ve teknemiz ters döndügünde bizi yemeyi bekleyen korkunç ve } \\
\text { tehlikeli canavarlar vardı bu masallarda. (s.32) } \\
\text { Bu sefer birbirimize başka masalar anlatmaya başladık. Gitmeye çalıştığımız ülkenin yemyeşil } \\
\text { ormanlarındaki dans eden iyilik perileri vardı masallarımızda. (s. 33) }\end{array}$ \\
\hline Y-15 & Önümüzde büyük bir deniz vardı. Göz alabildiğince uzanan kocaman bir deniz. (s. 30) \\
\hline Y-16 & $\begin{array}{l}\text { "Peki, orası nerede?" diye sorduk bu sefer. Bir kitaptan değişik şehirlerin fotoğraflarını gösterdi } \\
\text { annem. Oradaki ilginç ormanları, hayvanları anlattı, tek tek. Sonra iç çekerek şöyle dedi: "Oraya } \\
\text { gideceğiz ve artık korkmadan yaşayabileceğiz."(s.12) }\end{array}$ \\
\hline TBK-1 & $\begin{array}{l}\text { Ama bir sabah güneş o parlak yüzünü göstermedi. Onun yerine kapkaranlık bir bulut gelip adanın } \\
\text { üzerine âdeta demir attı. (s. 6) }\end{array}$ \\
\hline TBK-2 & $\begin{array}{l}\text { Tarık kendine arkadaş edinememişti. Kendini yalnız hissediyordu. (s. 18) } \\
\text { Gel zaman git zaman Beyaz Karga ve Tarık arkadaş oldular. (s. 20) }\end{array}$ \\
\hline TBK-3 & $\begin{array}{l}\text { Tarık ve kız kardeşi Layla, bu adada aileleriyle birlikte mutlu bir şekilde yaşıyorlardı. (s. 6) } \\
\text { Annesi, Tarık'a sarılarak "Layla ve ben burada büyükannen ve büyükbaban ile birlikte sizlerden } \\
\text { haber bekleyeceğiz." dedi. (s. 10) }\end{array}$ \\
\hline TBK-5 & $\begin{array}{l}\text { Beyaz karga teknenin etrafında uçarak âdeta onlara gidecekleri yönü gösteriyordu. Beyaz } \\
\text { karganın rehberliğinde ilerlerken birden Tarık bağırdı, "Kara göründü!". Gerçekten de ufukta bir } \\
\text { ada görünüyordu. Tarık ve babası çok heyecanlanmıştı. Beyaz karga onları kurtarmıştı. (s. 14) }\end{array}$ \\
\hline
\end{tabular}




\begin{tabular}{|c|c|}
\hline TBK-6 & $\begin{array}{l}\text { O acelede Tarık çok sevdiği flütünü suya düşürdü. Zamanı olsa hemen dalıp alırdı. Tarık çok iyi } \\
\text { bir yüzücü ve dalgıçtı. (s. 10) }\end{array}$ \\
\hline TBK-8 & $\begin{array}{l}\text { Ada halkı, Tarık ve babasını kıyıda bekliyordu. Tekne yanaşınca baba ve oğlun kıyıya çıkmasına } \\
\text { yardım edip onlara yiyecek ve su verdiler. Başlarına gelenleri sordular. Ada halkı iyi insanlardı. } \\
\text { Onlara kalacak bir ev verdiler. (s. 16) }\end{array}$ \\
\hline TKB-9 & Yeni adada çok balıkçı olduğu için Tarık'ın babası flüt ustası olarak çalışmaya başladı. (s.28) \\
\hline TBK-12 & $\begin{array}{l}\text { Tarık "Çok bitkinim babacığım. Yemeğimiz, suyumuz, şekerimiz de bitmek üzere. Ne yapacağız?" } \\
\text { diyerek babasına sarıldı. Babası cevap veremedi. Deniz suyu tuzlu olduğundan içemiyorlardı. (s. 12) }\end{array}$ \\
\hline TBK-13 & $\begin{array}{l}\text { Günlerce atölyelerde çalışıp bir rüzgâr makinası geliştirdiler. Makine rüzgâr üretip bulutu } \\
\text { kovmaya çalıştı ama yine fayda etmedi. (s. 8) }\end{array}$ \\
\hline TBK-14 & $\begin{array}{l}\text { Babası, Tarık'ı keyiflendirecek bir şey yapmak istedi. Alet kutusunu alıp odasına kapandı ve küçük } \\
\text { oğluna bir hediye hazırladı. Akşam olup eve geldiğinde Tarık masanın üzerinde bir de ne görsün? } \\
\text { Yepyeni bir flüt. O kadar sevinmişti ki "Flüt çalmayı çok özlemiştim.” diyerek babasına sarıldı. (s. 22) } \\
\text { Tarık o zaman bu adada eksik olan şeyi anladı: Müzik. Ada halkı ağacın etrafında dans } \\
\text { ederken kargalar da gökyüzünde daireler çizmeye başladı. Onlar da Beyaz Karga'nın şarkısını } \\
\text { sevmişlerdi. (s. 26) }\end{array}$ \\
\hline TBK-15 & $\begin{array}{l}\text { Uzak, çok uzak denizlerin orta yerinde, nokta gibi küçücük bir balıkçı adası vardı. Her sabah } \\
\text { yusyuvarlak, sapsarı bir güneş doğar, masmavi dalgalar sonsuzluğa doğru birbirini kovalardı. } \\
\text { Ağaçlar meyve dolu, şelalerin suyu buz gibiydi. (s. 4) } \\
\text { Teknenin ucuna beyaz bir kuş kondu. Bu bir leylek değildi. Bir martı da değildi. Kesinlikle beyaz } \\
\text { bir papağan da değildi. Bu kar beyaz gibi bir kargaydı. (s. 14) }\end{array}$ \\
\hline TBK-16 & $\begin{array}{l}\text { Yeni ada güzel bir adaydı. Ama bir şeyler eksikti. Bu adadaki insanlar hiç gülmüyordu. Sürekli } \\
\text { başları ağrıyordu. (s. 18) } \\
\text { Tarık ve ailesi bu adada mutlu olsalar da eski adalarını hiç unutmadılar. Tarık, Layla’ya sarılıp } \\
\text { şöyle demişti: "Bir gün o kapkara bulut gidecek ve biz yurdumuza döneceğiz." (s. 28) }\end{array}$ \\
\hline $\mathrm{AK}-2$ & $\begin{array}{l}\text { Akim kampta güvende. Ama sürekli ailesini ve şahit olduğu onca şeyi düşünmeden edemiyor. } \\
\text { Diğer çocuklarla oyun oynamak içinden gelmiyor bir türlü. (s. } 75 \text { ) }\end{array}$ \\
\hline AK-3 & $\begin{array}{l}\text { Akim ailesini istiyor. (s. 10) } \\
\text { Akim ağlıyor. "Anne, anne..." (s. 26) } \\
\text { Akim sık sık kayıp ailesinin yasını tutup geçmişini düşünüyor. (s. 81) }\end{array}$ \\
\hline AK.4 & Akim'in köyünde savaştan iz yoktu, savaş uzak gibiydi. (s. 2) \\
\hline AK-5 & $\begin{array}{l}\text { Yolda bir insani yardım kuruluşunun kamyonuyla karşılaşıyorlar. Kamyon onları alıp bir mülteci } \\
\text { kampına götürüyor. (s. 67) }\end{array}$ \\
\hline $\mathrm{AK}-7$ & $\begin{array}{l}\text { Akim, Kuma Nehri’nin kıyısında diğer çocuklarla birlikte küçük kayıklarla oyun oynuyor, huzur } \\
\text { içinde. (s. 2) } \\
\text { Bir gün askeri kampta roket sesleri yankılanıyor. Askerler silahlarıyla dışarı firlıyor. (s. 46) }\end{array}$ \\
\hline AK-8 & $\begin{array}{l}\text { Akim saatlerce dağlık bölgede ilerledikten sonra savaştan kaçan bir grup insanla karşılaşıyor. } \\
\text { Onların yanına koşuyor. İhtiyar bir kadın, Akim’e elini uzatıyor. (s. 53) } \\
\text { Sınır! Bir balıkçı onları kayığına alıyor, birlikte suya açılıyorlar. (s 59.) }\end{array}$ \\
\hline AK-12 & $\begin{array}{l}\text { Akşam ona yemesi için azıcık pirinç lapası veriyorlar. (s. 36) } \\
\text { Orada karınlarını doyurma ve yıkanma olanağı buluyorlar. Artık geceleri uyuyabilecekleri bir } \\
\text { yatakları var. (s. } 67 \text { ) }\end{array}$ \\
\hline AK-14 & O akşam Akim diğerleriyle birlikte Binbir Gece Masalları'nı dinliyor. (s. 75) \\
\hline
\end{tabular}

Tablo 5'te sunulan örnek ifadeler incelendiğinde çocuğa yönelik duyarlık kazandırmanın kimi zaman ele alınan duyarlığın zıddı ile sağlanmaya çalışıldığı görülmektedir. Örneğin Akim Koşuyor'da barışa karşı duyarlık, savaşın anlatımıyla sağlanmaya çalışılmaktadır. Duyarlık eğitimini örtük ifadelerle gerçekleştirme gayreti, çocuğun duyarlık geliştirmesine katkı sağlamasının yanı sıra etkin okur kimliği kazanmasını da desteklemesi adına önemlidir. 


\section{Sonuç}

Göç ve mültecilik konulu Arkadaşım Korku, Kayıktaki Çocuk, Yolculuk, Tarık ve Beyaz Karga ile Akim Koşuyor adlı çocuk kitapları, duyarlık eğitimi açısından belirlenen 16 kategori esas alınarak incelenmiştir. Yapılan inceleme sonucunda 16 duyarlık kategorisinden sadece "yoksul insanlara duyarlık", değerlendirilen kitaplarda saptanamamıştır. Geriye kalan 15 duyarlık konusunun farklı oranlarda kitaplarda yer aldığı belirlenmiştir. Çalışma kümesindeki kitaplarda en çok sevgiye duyarlık, kültürel duyarlık, aile bireylerine duyarlık, toplumsal huzura duyarlık, doğaya duyarlık, dilsel duyarlık, temel yaşam ihtiyaçlarına duyarlık ve iyilik yapmaya duyarlığa yer verildiği görülmüştür. Bu da incelenen kitapların duyarlık konuları açısından zengin bir malzeme sunduğunu göstermektedir. Adı geçen kitapları okuyan çocuğun, belli bir ölçüde farklı konularda duyarlık kazanacağı söylenebilir. Dolayısıyla çocuk edebiyatının amacı olan insana özgü duyarlıkların çocuğa yazınsal bir kurgu içinde sunulmasının, incelenen kitaplar aracılığıyla sağlanabileceği düşünülmektedir.

Toplumu anlamak, ona uyum sağlamak, farklılıkları kavramak ve bu farklılıklara saygı duymak için eğitim önemlidir. Erkan ve Erdoğdu da göçün mülteci çocuklar üzerindeki olumsuz psikolojik etkilerinin ancak eğitime ulaşımlarının artırılması ile giderileceğini savunmaktadır. ${ }^{27}$ Böyle bir eğitimde çocuk edebiyatının kurmaca dünyası, çocuğu toplumsal yaşantıya hazırlama noktasında işlevsel bir kaynak olarak ele alınmaktadır. ${ }^{28}$ Mülteci çocukların yaşadıklarının sadece kendilerine özgü olmadığını anlamaları; ev sahibi akranlarının, onları farklılıkları ile kabul etmeleri için kitaplar aracılığıyla verilecek duyarlık eğitiminden daha etkili bir yol olamayacağı düşünülmektedir. Bu sebeple çocuk edebiyatı eserlerinin duyarlık eğitimi bağlamında etkililiğini ve sahip olduğu iletilerin taşıması gereken özellikleri araştıran çalışmaların sayısına olan ihtiyacın, hedef kitlenin nitelikleri dikkate alındığında, artması gerektiği ifade edilebilir. ${ }^{29}$ Bu çalışmada Arkadaşım Korku, Kayıktaki Çocuk, Yolculuk, Tarık ve Beyaz Karga ile Akim Koşuyor göç ve mültecilik konularını ele alırken çocuk duyarlığını yansıtma düzeyi bakımından değerlendirilmiştir. Birinin, ötekini anlama çabasına ortak olma adına bu konuda kaleme alınan çocuk edebiyatı ürünlerini farklı açılardan değerlendirilen çalışmalara ihtiyaç duyulduğu da bir gerçektir.

27 Rüstem Erkan ve M. Yüksel Erdoğdu, "Göç ve Çocuk Suçluluğu”, Aile ve Toplum Eğitim Kültür ve Araşttrma Dergisi 3/9 (2006), 79-90.

28 Elif Emine Balta, "Çocuk Kitaplarında Mülteciler ve Kültürleşme Stratejileri", Gaziantep University Journal of SocialSciences 17/2 (2018), 487-498.

29 Karakuş Tayşi, "Sevim Ak'ın Öykülerinin Duyarlık Eğitimi Açısından İncelenmesi”, 303-324., Pınar Etoğlu Kibris, Çocuk Edebiyatı Eserlerinin Duyarlık Eğitimi Bağlamında İncelenmesi: Gülten Dayığlu Örneği (Yüksek Lisans Tezi, Kütahya Dumlupınar Üniversitesi, 2019), K. Evsen, Mustafa Ruhi Şirin 'in Çocuk Şiirleri ve Masallarının Duyarlık Eğitimi Açısından İncelenmesi (Yüksek Lisans Tezi, Kütahya Dumlupınar Üniversitesi, 2019), Aslan, "Duyarlık ve Düşünceyi Geliştirmede Çocuk/Gençlik Edebiyatı", 29-32., Canan Aslan, Oğuz Tansel'in Derleyip Yazdığı Masalların Duyarlık Eğitimi Bağlamında İncelenmesi, haz. S. Sever ve S. Karagül, Uluslararası Türk Masal Dünyası ve Doğumunun Yüzüncü Yllında Oğuz Tansel Sempozyumu içinde (Ankara Üniversitesi Çogem, Odtü, 2016), Alamdar ve Süngü, "Nâzım Hikmet'in Sevdalı Bulut adlı kitabındaki masalların duyarlık eğitimi bağlamında incelenmesi”, 301-305. 
Hakem Değerlendirmesi: Dış bağımsız.

Çıkar Çatışması: Yazar çıkar çatışması bildirmemiştir.

Finansal Destek: Yazar bu çalışma için finansal destek almadı̆̆ını beyan etmiştir.

Peer-review: Externally peer-reviewed.

Conflict of Interest: The author has no conflict of interest to declare.

Grant Support: The author declared that this study has received no financial support.

\section{Kaynaklar/References}

Akay Selçuk, Hamamcı Zeynep ve Kurt Mahmut. "Suriyeli Öğrencilerle Çalışan Psikolojik Danışmanların Yaşadıkları Sorunlar ve Bu Sorunlara İlişsin Uyguladıkları Çözüm Yollarının İncelenmesi”, Gaziantep Üniversitesi Ĕgitim Bilimleri Dergisi 1/1 (2017): 23-47.

Alamdar Suphi Güneş ve Süngü, Arzu. "Nâzım Hikmet' in Sevdalı Bulut Adlı Kitabındaki Masalların Duyarlık Eğitimi Bağlamında İncelenmesi”, Tacettin Şimşek ve Bican Veysel Yıldız. (Editör), IV. Uluslararası Çocuk ve Gençlik Edebiyatı Sempozyumunda Sunulan Bildiri Kitabı: 1. Cilt içinde s. 301-315, İstanbul, Step Matbaac1lik, 2017.

Arastaman Gökhan, Fidan Öztürk İnci ve Fidan Tuncer. "Nitel Araştırmada Geçerlik ve Güvenirlik: Kuramsal Bir İnceleme”, YYÜ Eğitim Fakültesi Dergisi 15/1 (2018): 37-75.

Aslan Canan. "Duyarlık ve Düşünceyi Geliştirmede Çocuk/Gençlik Edebiyatı", Çoluk Çocuk Dergisi 1/102 (2013): 29-32.

Aslan Canan. "Oğuz Tansel'in Derleyip Yazdığı Masalların Duyarlık Eğitimi Bağlamında İncelenmesi”, S. Sever ve S. Karagül (Hazırlayan), Uluslararası Türk Masal Dünyası ve Doğumunun Yüzüncü Yılında Oğuz Tansel Sempozyumu içinde s.131-152, Ankara Üniversitesi Çogem, Odtü, 2016.

Balta Elif Emine. "Çocuk Kitaplarında Mülteciler ve Kültürleşme Stratejileri”, Gaziantep University Journal of Social Sciences 17/2 (2018): 487-498.

Binyazar Adnan. “Anadili Kitaplarında Yazınsal Metinlerden Yararlanılarak Duyarlık Eğitimini Gerçekleştirme”, H. Coşkun, İ. Kaya, J. Kuglin (Editör), Türkiye ve Almanya'da İlköğretim Ders Kitapları içinde, Türk Alman Kültür İşleri Kurulu Yayın Dizisi, No.11, 1996.

Bulut, Sevilay. “Çocuk Edebiyatına Sığınanlar: Zorunlu Göç Öyküleri”, OPUS 8/14 (2018): 383-410.

Buz, Sema. "Türkiye'deki Siğınmacıların Üçüncü Bir Ülkeye Gidiş İ̧̧in Bekleme Sürecinde Karşılaştıkları Sorunlar”. Yüksek Lisans Tezi. Hacettepe Üniversitesi, 2002.

Ergene, T. "Risk Altındaki Çocuklara İlişkin Psikososyal Destek.” Erişim 23 Şubat 2020. https://pictes.meb. gov.tr/izleme/Content/Dosyalar/02173627_Risk_AltYndaki_Yocuklara_YliYkin_Psikosyal_Destek_ Tuncay_Ergene_Antalya_YalYYtayY.pdf.

Erkan Rüstem ve Erdoğdu M. Yüksel. "Göç ve Çocuk Suçluluğu”, Aile ve Toplum Eğitim Kültür ve Araştırma Dergisi 3/9 (2006): 79-90.

Evsen, K. "Mustafa Ruhi Şirin'in Çocuk Şiirleri ve Masallarının Duyarlık Eğitimi Açısından İncelenmesi”. Yüksek Lisans Tezi, Kütahya Dumlupınar Üniversitesi, 2019.

IOM. “Göç Terimleri Sözlüğü.” İkinci Bask1. Erişim 23 Şubat 2020. https://publications.iom.int/system/files/ pdf/iml31_turkish_2ndedition.pdf, 2009. 
Karakaşlı Karin. “Umut ve Hayal Herkese Lazım”, İyi Kitap Çocuk ve Gençlik Kitapları Dergisi 5 (2017): 8-9.

Karasar, Niyazi. Bilimsel Araştırma Yöntemi. Ankara: Nobel Yayın Dağıtım, 2006.

Kibris, Etoğlu, Pınar. “Çocuk Edebiyatı Eserlerinin Duyarlık Eğitimi Bağlamında İncelenmesi: Gülten Dayıŏ̆lu Örneği”. Yüksek Lisans Tezi, Kütahya Dumlupınar Üniversitesi, 2019.

Korkmaz Safter. "Çocuk Kitaplarında Göç ve Mültecilik”, İyi Kitap Çocuk ve Gençlik Kitapları Dergisi 5 (2017): 1-3.

Öngören Sema, Özkan Ahsen., Yüksel Büşra ve Sever Doğukan. "Göçmen Çocukların Yaşadıkları Uyum Problemlerinin Öğretmen Görüşleri Açısından İncelenmesi”, Akademik Sosyal Araştırmalar Dergisi 5/59 (2017): 147-159.

PICTES. Okul Çağındaki Suriyeli Çocuk Sayısı (Broşür). Ankara, 2019.

Sarıtaş Emel, Şahin Ümran ve Çatalbaş Gülsüm. "İlkokullarda Yabancı Uyruklu Öğrencilerle Karşılaşılan Sorunlar”, Pamukkale Üniversitesi Sosyal Bilimler Enstitüsü Dergisi 25/1 (2016): 208-229.

Sever, Sedat. Çocuk Edebiyatı ve Okuma Kültürü. İzmir:Tudem, 2013.

Simich Laura ,Beiser, Morton ve Mawani, Farah N. "Social Support and the Significance of Shared Experience in Refugee Migration and Resettlement”, Western Journal of NursingResearch 25/7 (2003): 872-891.

Şahin Muhammed ve Doğan Yakup. "Suriyeli öğrencilerin bulunduğu sinıflarda Fen Bilimleri öğretiminde karşılaşılan sorunlar: Nitel bir çalışma”, Uluslararası Eğitim Araştırmacıları Dergisi 1/1 (2018): 13-33.

Şensin, Ceyda. “Sınıf Öğretmenlerinin Suriye’den Göçle Gelen Öğrencilerin Ĕ̆itimlerine İlişkin Görüşlerinin Değerlendirilmesi”. Yüksek Lisans Tezi, Uludağ Üniversitesi, 2016.

Tayşi Karakuş Esra. “Sevim Ak’ın Öykülerinin Duyarlık Eğitimi Açısından İncelenmesi”, Dil ve Edebiyat Araştırmaları 19 (2019): 303-324.

Whitaker, Elizabeth. Language Acquisition of Thechildren of Immigrantsandthe Role of Nonprofit organizations. Washington: University of Puget Sound, 2010.

Yakushko, Oksana ve Morgan M. L. "Immıgration", R. A. Young, J. F. Domene ve L. Valach (Editör). Counselingand Action içinde, Springer, New York, 2012.

Yıldırım, Ali ve Şimşek, Hasan. Sosyal Bilimlerde Nitel Araştırma Yöntemleri. Ankara: Seçkin Yayıncılık, 2011. Yiğit, Tuğba. “Uygulamalar ve Sorunlar Băglamında Türkiye’de Sı̆̆ınmacı Çocukların Ĕgitimi (Kırşehir ve Nevşehir Örneği)”. Yüksek Lisans Tezi, Ahi Evran Üniversitesi, 2015.

\section{İncelenen Kitaplar}

Sanna, Francesca. Arkadaşım Korku. Çeviren Zeynep Sevde. Ankara: Taze Kitap, 2018.

Sanna, Francesca. Yolculuk. 2. Bask1. Çeviren Zeynep Sevde. Ankara: Taze Kitap, 2016.

Kutup Y1ldıı Kolektifi. Tarık ve Beyaz Karga. 2. Baskı. İstanbul: Sarıgaga Yayıncılık, 2018.

Dubois, Claude. K. Akim Koşuyor. Çeviren Ferhat Sarı. İstanbul: Ginko Çocuk, 2019.

Okçu, Sevde Tuba, Mizuno, Maya, Hemels, Vonne ve Sweet, Golden. Kayıktaki Çocuk. 3. Basım. Çeviren Sevde Tuba Okçu. İstanbul: Timaş Basım, 2018. 
